Web Jurnal:

http://ejournal.kemenperin.go.id/jli

\title{
Produksi garam di lahan geomembran: Perhitungan kapasitas produksi, mutu dan perbandingannya dengan garam tradisional
}

\section{Salt production in geomembrane land: Calculation of production capacity, quality and comparison with tradisional salt}

\author{
Lancy Maurina *, Mahlinda, Abdul Thalib, dan Ridho Kurniawan \\ Balai Riset dan Standardisasi Industri Banda Aceh \\ Jl. Cut Nyak Dhien No. 377 Lamteumen Timur, Banda Aceh, Indonesia \\ * e-mail: lancymaurin@gmail.com
}

\begin{tabular}{|c|c|}
\hline INFO ARTIKEL & ABSTRAK \\
\hline $\begin{array}{l}\text { Sejarah artikel: } \\
\text { Diterima : } \\
\text { 30 Maret } 2021 \\
\text { Direvisi : } \\
\text { 20 Desember } 2021 \\
\text { Diterbitkan : } \\
\text { 30 Desember } 2021\end{array}$ & $\begin{array}{l}\text { Provinsi Aceh merupakan salah satu daerah penghasil garam di Indonesia. Secara umum, } \\
\text { proses pengolahan garam di Provinsi Aceh masih dilakukan secara tradisional dengan } \\
\text { cara perebusan air garam menggunakan kayu bakar sebagai pemanas hingga air menguap } \\
\text { dan menyisakan butiran garam berwarna putih buram. Teknologi perebusan ini memiliki } \\
\text { beberapa kekurangan diantaranya harga kayu bakar semakin mahal, jumlah produksi } \\
\text { sangat terbatas dan mutu garam yang dihasilkan masih rendah. Penelitian ini bertujuan } \\
\text { untuk mempelajari proses kristalisasi garam menggunakan teknik geomembran, } \\
\text { menghitung kapasitas produksi dan menguji produk garam yang dihasilkan sesuai dengan }\end{array}$ \\
\hline $\begin{array}{l}\text { Kata kunci: } \\
\text { garam; } \\
\text { geomembran; } \\
\text { mutu; } \\
\text { tradisional }\end{array}$ & $\begin{array}{l}\text { Standar Nasional Indonesia (SNI) 3556:2010. Hasil penelitian menunjukkan pada lahan } \\
\text { geomembran yang terdiri dari empat meja garam dengan ukuran masing-masing } \mathrm{P} 9 \mathrm{x} \mathrm{L} \\
3,8 \times \mathrm{T} 0,20 \mathrm{~m} / \mathrm{meja} \text {, yang dikelola oleh satu orang tenaga kerja, pada kondisi cuaca } \\
\text { normal dapat menghasilkan garam sebanyak } 2.000 \mathrm{~kg} / 10 \text { hari dengan kadar NaCl } 96,4 \% \\
\text { memiliki warna putih mengkilat dimana hasil uji ini telah memenuhi persyaratan } \mathrm{SNI} \text {. } \\
\text { Sementara pengolahan garam tradisional menggunakan pemanas kayu bakar dengan } \\
\text { ukuran meja kristalisasi P } 2,4 \times \mathrm{L} 1,2 \times \mathrm{T} 0,20 \mathrm{~m} \text { yang juga dikelola oleh satu oarng } \\
\text { tenaga kerja hanya dapat menghasilkan garam sebanyak } 900 \mathrm{~kg} / 10 \text { hari dengan kadar } \\
\mathrm{NaCl} 90,28 \% \text { memiliki warna putih buram. }\end{array}$ \\
\hline
\end{tabular}

\footnotetext{
Keywords:

salt;

geomembrane;

quality;

traditional
}

\begin{abstract}
Aceh Province is one of the salt-producing areas in Indonesia. In general, the process of salt production is still done traditionally by boiling salt water using fire wood as heater until the water evaporates and forms frosted white crystalline salt. This boiling technology has several drawbacks as the high price of fire wood, and the low quantity and quality of the salt produced. This research aims to study the crystallization process of salt using high-density polyethylene (HDPE) geomembrane, calculating production capacity and test products according to SNI 3556:2010. The results showed that using geomembrane pond consisting of four salt table with dimension of $L 9 x \mathrm{~W} 3,8 \times H$ 0,20 $\mathrm{m} / \mathrm{table}$, which were managed by one worker, in normal weather can produce 2.000 $\mathrm{kg} / 10$ days with $\mathrm{NaCl}$ content $96,4 \%$ with have shimering white colour, this parameter tested were complied with SNI. Meanwhile, tradistional salt processing using fire wood as heater with salt table dimension of L 2,4 $x \mathrm{~W} \mathrm{1,2} \times \mathrm{H} \mathrm{0,20} \mathrm{m}$ which also managed by one worker can produce salt only $900 \mathrm{~kg} / 10$ days with $\mathrm{NaCl}$ content 90,28\% have dark white colour.
\end{abstract}




\section{Pendahuluan}

Garam merupakan salah satu mineral alam yang paling banyak dikonsumsi oleh manusia baik secara langsung sebagai bumbu masak ataupun digunakan secara tidak langsung sebagai pengawet makanan dan bahan penolong industri. Umumnya garam dapat diperoleh dari tiga cara, yaitu dengan cara penambangan batuan garam (rock salt mining), sumur air garam (brine) dan dengan proses penguapan air laut menggunakan bantuan sinar matahari atau memasak air garam menggunakan bahan pemanas seperti kayu bakar dan biomass (Guntur et al., 2018; Rochwulaningsih, 2018).

Dilihat secara fisik, garam berbentuk padatan kristal berwarna putih bening atau buram (tergantung tingkat kemurniannya) dengan komponen terbesar yaitu natrium chloride $(\mathrm{NaCl})$ diatas $80 \%$ dan beberapa komponen kecil lainnya seperti magnesium dichloride $\left(\mathrm{MgCl}_{2}\right)$, magnesium sulfate $\left(\mathrm{MgSO}_{4}\right)$, calcium chloride $\left(\mathrm{CaCl}_{2}\right)$ serta pengotor. Secara umum, garam tidak hanya digunakan di bidang pangan saja, tetapi juga digunakan di berbagai bidang industri seperti untuk bahan baku pembuatan caustic soda $(\mathrm{NaOH})$, monosodium glutamate (MSG), bahan penolong pada proses pengolahan air (water treatment), bahan-bahan medis/obat-obatan dan berbagai aplikasi lainnya (Tansil et al., 2016).

Saat ini, kebutuhan akan komoditas garam di Indonesia terus meningkat setiap harinya. Diperkirakan pada tahun 2020 ini kebutuhan garam nasional mencapai 4.464.670 ton, namun kapasitas produksi hanya sebesar 2.327.078 ton sehingga terdapat kekurangan pasokan garam sebesar 2.137.592 ton (Amien and Adrienne, 2020). Indonesia yang memiliki garis pantai terpanjang ke dua di dunia setelah negara Canada (Lasabuda, 2013) memiliki beberapa daerah utama penghasil garam terbesar yaitu Jawa Timur, Jawa Barat, Jawa Tengah, Bali, Nusa Tenggara Timur (NTT), Nusa Tenggara Barat (NTB), Sulawesi Utara, Sulawesi Selatan, Sulawesi Tengah, Gorontalo, Aceh dan beberapa daerah lainnya (Arif Abdullah and Susandini, 2018).

Munculnya inovasi baru dalam hal pengolahan garam yang lebih praktis dan efisien misalnya dengan menggunakan teknologi geomembran, telah mendorong sebagian petani garam beralih menggunakan teknologi tersebut karena hasil produksinya lebih tinggi dan memiliki kualitas (mutu) yang lebih baik karena pada saat di produksi tidak bercampur dengan tanah serta kotoran (Arif Abdullah and Susandini, 2018). Geomembran merupakan sejenis plastik berwarna hitam dari bahan High Density Poliethylene (HDPE) yang tahan terhadap panas tinggi dan cairan kimia/biologi, anti korosi dan tahan terhadap sinar ultraviolet (Suhendra, 2016). Plastik geomembran tersedia dalam beberapa ketebalan, namun yang paling sesuai untuk lahan garam adalah dengan ketebalan 0,5-2 $\mathrm{mm}$. Penggunaan geomembran HDPE pada lahan garam mendapatkan beberapa keuntungan yaitu: (a) mencegah terjadinya pencemaran garam dengan partikel lainnya/kotoran, (b) meningkatkan produktifitas garam, (c) kadar $\mathrm{NaCl}$ lebih tinggi, (d) mempercepat proses kristalisasi garam (Hoiriyah U., 2019).
Provinsi Aceh merupakan salah satu daerah penghasil garam di Indonesia, dengan daerah utama penghasil garam terdapat di Kabupaten Aceh Besar, Pidie, Pidie Jaya, Bireuen, Aceh Utara, Aceh Timur, Aceh Barat Daya (Abdya), Aceh Selatan, Aceh Tamiang dan Pulau Simeuleu (Mauliza et al., 2016). Umumnya, proses produksi garam di Provinsi. Aceh masih menggunakan teknologi kristalisasi garam dengan cara perebusan air garam menggunakan kayu bakar yang dilakukam selama \pm 4 jam hingga air menguap dan menyisakan butiran garam berwarna putih buram. Meskipun teknologi penguapan air garam menggunakan sumber pemanas dari kayu bakar telah digunakan turun menurun hingga sekarang, namun dalam kenyataannya masih ditemukan banyak kendala diantaranya: harga kayu bakar semakin lama semakin mahal, jumlah produksi sangat terbatas dan mutu garam yang dihasilkan masih rendah. Kendala-kendala tersebut menyebabkan biaya operasional tinggi sehingga harga jual garam tradisional lebih mahal, hanya dapat memproduksi garam dalam jumlah terbatas dan kadar $\mathrm{NaCl}$ masih rendah sehingga belum memenuhi persyaratan mutu SNI 3556-2010.

Penelitian ini bertujuan untuk mempelajari proses kristalisasi garam di lahan geomembran, menghitung kapasitas produksi dan menguji produk sesuai SNI. Hasil yang diperoleh dibandingkan dengan proses produksi garam tradisional.

\section{Metode \\ 2.1. Bahan dan alat}

Bahan-bahan utama yang digunakan untuk penelitian ini berupa geomembran HDPE warna hitam ketebalan 2 $\mathrm{mm}$, plastik terpal putih ketebalan $2 \mathrm{~mm}$, kayu reng, pipa air PVC dan air garam tua (sekitar $25^{\circ}$ baume). Peralatan yang digunakan berupa HP OPPO A7 (mengukur titik koordinat melaui Google Map), pengukur kecepatan angin, temperatur dan kelembaban udara (Kestrel 4500 NV), gergaji kayu, bor tangan, pompa air, baskom, timbangan, cangkul, dan peralatan penolong lainnya.

\subsection{Waktu dan tempat}

Penelitian dilaksanakan selama 10 bulan mulai dari bulan Maret hingga Desember 2020 dengan lokasi penelitian di ladang garam UD. Milhy Jaya Desa Tanoh Anoe Kecamatan. Jangka Kabupaten Bireuen Provinsi Aceh. Sedangkan pengujian produk garam di lakukan di Laboratorium Kimia Baristand Industri Banda Aceh.

\subsection{Pelaksanaan penelitian}

Penelitian diawali dengan survei lokasi dengan parameter yang diukur terdiri dari titik koordinat melalui Google Map menggunakan HP OPPO A7, dilanjutkan dengan mengukur temperatur, kelembaban dan kecepatan angin menggunakan alat Weather Meter Kestrel 4500 NV. Penelitian dilanjutkan dengan pengujian mutu air sumur bor dengan parameter kadar $\mathrm{NaCl}$ menggunakan sistim titrasi dan cemaran logam yang terdiri dari uji kadmium $(\mathrm{Cd})$, timbal $(\mathrm{Pb})$, raksa (Hg) dan arsen (As) menggunakan alat Atomic Absorption Spectrophotometer (SHIMADZU AA-7000). 
Kegiatan dilanjutkan dengan pembuatan meja kristalisasi garam geomembran model lorong (tunnel) dengan ukuran L 4,2 x P 20 x T 0,2 mtr. Adapun bentuk dari meja kristalisasi tersebut dapat dilihat pada Gambar 1. Meja kristalisasi garam di isi dengan air garam tua (sekitar $25^{\circ}$ baume) dan diuapkan menggunakan sinar matahari selama 8-10 hari (tergantung cuaca) hingga air garam tua berubah menjadi kristal garam bewarna putih. Produk garam diambil untuk dilakukan pengujian produk sesuai dengan persyaratan mutu SNI. Sebagai bahan pembanding juga dilakukan pengambilan data produksi garam tradisional menggunakan penguapan dengan panas dari pembakaran kayu bakar dilakukan dengan cara wawancara langsung ke petani garam tradisional, juga dengan mengambil sampel garam tradisional dan dilakukan pengujian sesuai dengan persyaratan mutu SNI. Hasil dari penelitian diolah dan ditampilkan dalam bentuk Tabel serta Gambar.

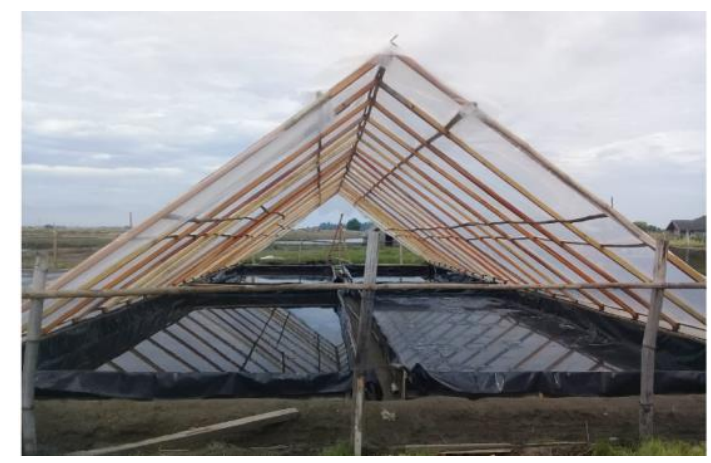

Gambar 1. Meja kristalisasi garam geomembran HDPE 2 mm model lorong (tunnel)

\section{Hasil dan pembahasan \\ 3.1. Hasil survei lokasi}

Kondisi lingkungan seperti temperatur, kecepatan angin, kelembapan udara dan curah hujan sangat berpengaruh terhadap tingkat produktifitas garam di mana pada kondisi yang ideal dapat mempercepat laju penguapan air yang secara langsung dapat mempercepat proses kristalisasi garam. Survey lokasi ini bertujuan untuk mengetahui beberapa parameter yang ideal untuk pembuatan lahan garam geomembran. Parameter yang diukur terdiri dari titik koordinat, temperatur udara, kelembapan udara, kecepatan angin, curah hujan dan rata-rata hari hujan/tahun. Hasil survey lokasi dapat dilihat pada Tabel 1 di bawah ini.

Tabel 1.

Hasil survei lokasi

\begin{tabular}{|c|c|c|}
\hline Parameter & Satuan & Hasil \\
\hline Titik Koordinat & - & $5^{\circ} 15^{\prime} 05.9 \mathrm{~N} \mathrm{96} 46^{\circ} 03.1^{\prime \prime} \mathrm{E}$ \\
\hline Temperatur udara & ${ }^{\circ} \mathrm{C}$ & $32-38$ \\
\hline Kelembapan udara & $\%$ & $45-50$ \\
\hline Kecepatan Angin & $\mathrm{m} / \mathrm{dtk}$ & $4-5$ \\
\hline Curah hujan (rata-rata) & $\mathrm{mm}$ & $1.447^{*}$ \\
\hline $\begin{array}{l}\text { Rata-rata curah } \\
\text { hujan/tahun }\end{array}$ & hari & $92^{*}$ \\
\hline
\end{tabular}

*Sumber: (Karya, 2015)
Berdasarkan data dari Tabel 1 diketahui bahwa lokasi yang disurvey sangat cocok untuk dijadikan lahan garam geomembran karena memiliki kondisi lingkungan yang ideal diantaranya memiliki curah hujan 1,447 mm dengan rata-rata curah hujan 92 hari/tahun, temperatur $32-38{ }^{\circ} \mathrm{C}$ dengan tigkat kelembapan udara $45-50 \%$ dan kecepatan angin 4-5 m/detik. Menurut (Adi et al., 2006), untuk menghasilkan produk garam yang optimum diperlukan lokasi lahan garam yang memiliki iklim dan cuaca sebagai berikut: kecepatan angin diatas $5 \mathrm{~m} /$ detik, temperatur udara diatas $32{ }^{\circ} \mathrm{C}$, kelembapan udara dibawah 50\%, curah hujan rendah (1000 - 13000 $\mathrm{mm} /$ tahun), dan memiliki musim kemarau panjang yang kering tanpa diselingi hari hujan. Selain itu, kondisi tanah yang dijadikan lahan garam geomembran juga sangat ideal karena memiliki struktur tanah yang landai dan rata seperti yang disajikan pada Gambar 2 .
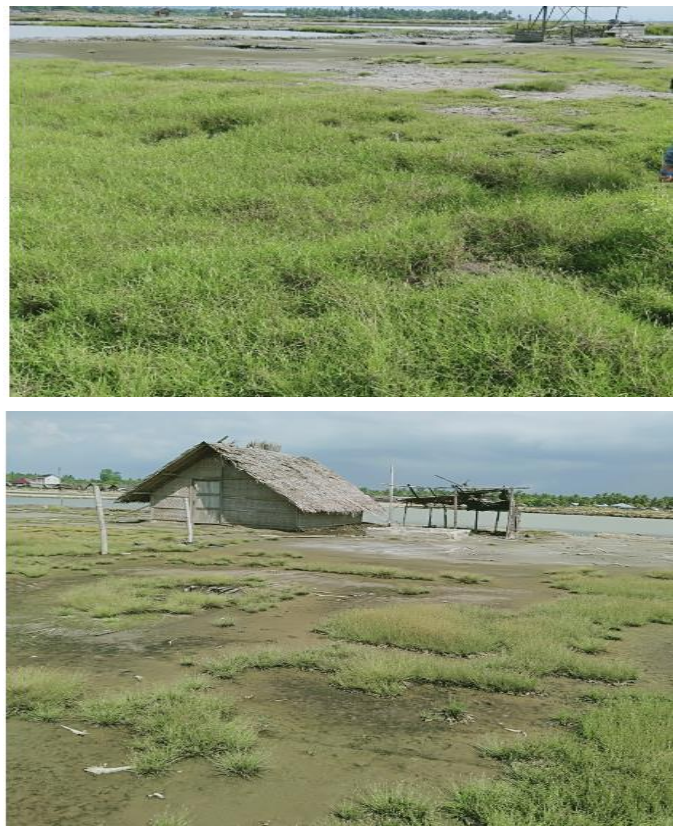

Gambar 2. Kondisi tanah untuk lahan garam geomembran

\subsection{Pengujian air baku}

Kondisi air baku yang digunakan untuk proses kristalisasi garam sangat berpengaruh terhadap mutu garam, dimana kualitas garam dipengaruhi banyaknya kandungan $\mathrm{NaCL}$ dan kandungan $\mathrm{NaCL}$ tersebut dipengaruhi oleh kondisi air baku yang digunakan (Arwiyah et al., 2015). Air baku yang digunakan untuk proses kristalisasi garam pada penelitian ini berasal dari air sumur bor. Penggunaan air sumur bor dilakukan karena lokasi penelitian agak jauh dari pantai dan tidak terdapat saluran air yang langsung berhubungan dengan aliran air laut. Sampel air sumur bor pada kedalam 6 meter diambil sebanyak $250 \mathrm{ml}$ (pada saat musim kemarau) dan dilakukan pengujian dengan parameternya adalah kadar NaCL dan cemaran logam (kadmium, timbal, raksa, arsen). Hasil pengujian air sumur bor tersebut dapat dilihat pada Tabel 2. 
Tabel 2.

Hasil uji air sumur bor

\begin{tabular}{llll}
\hline No. & Parameter & Satuan & Hasil uji \\
\hline 1. & Kadar NaCL & $\%$ & 3,78 \\
2. & Cemaran logam & & \\
2.1 & Kadmium $(\mathrm{Cd})$ & $\mathrm{mg} / \mathrm{kg}$ & $<0,0002^{*}$ \\
2.2 & Timbal $(\mathrm{Pb})$ & $\mathrm{mg} / \mathrm{kg}$ & $<0,0001^{*}$ \\
2.3 & Raksa $(\mathrm{Hg})$ & $\mathrm{mg} / \mathrm{kg}$ & $<0,0005^{*}$ \\
2.4 & Arsen $(\mathrm{As})$ & $\mathrm{mg} / \mathrm{kg}$ & $<0,0002^{*}$ \\
\hline "Batas & deteksi alat & &
\end{tabular}

Salah satu parameter terpenting untuk menentukan kelayakan air sumur bor agar dapat digunakan untuk bahan baku pembuatan garam adalah pada kadar garam yang terkandung di dalam air tersebut di mana semakin tinggi kadar garam semakin baik untuk digunakan sebagai sumber bahan baku pembuatan garam. Berdasarkan data pada Tabel 2 diketahui bahwa air sumur bor yang diuji mempunyai kadar $\mathrm{NaCl}$ sebesar $3,78 \%$ di mana hasil ini sudah sesuai dengan persyaratan yang ditentukan. Secara umum, konsentrasi garam di dalam air baku yang cocok digunakan untuk bahan baku pembuatan garam adalah antara 3-3,5\% (Santosa, 2014). Faktor lainnya yang berpengaruh terhadap kelayakan air baku untuk pembuatan garam adalah pada kandungan logamnya dimana kandungan logam yang berlebihan dapat berbahaya bagi kesehatan manusia jika dikonsumsi. Hasil pengujian kandungan logam dalam air sumur bor menunjukkan nilai yang sangat rendah (di bawah batas deteksi alat).

\subsection{Proses kristalisasi garam}

Salah satu tahapan penting dari proses kristalisasi garam adalah pada fase pertumbuhan kristal garam. Tahap ini sangat berperan dalam menghasilkan kualitas dan kuantitas garam. Pada proses kristalisasi garam di lahan geomembran pada penelitian ini, larutan air garam tua dengan konsentrasi garam sekitar 24-25 baume dimasukkan ke dalam meja kristalisasi menggunakan pompa air. Selanjutnya air garam tua tersebut diendapkan selama 8-10 hari. Pada saat pengendapan, air akan menguap secara perlahan-lahan tergantung dari kondisi cuaca menyebabkan konsentrasi garam meningkat hingga mencapai 30 baume dan akan membentuk butiran-butiran kristal garam. Adapun bentuk dari meja kristalisasi garam dan bentuk garam yang dihasilkan dapat dilihat pada Gambar 3 .

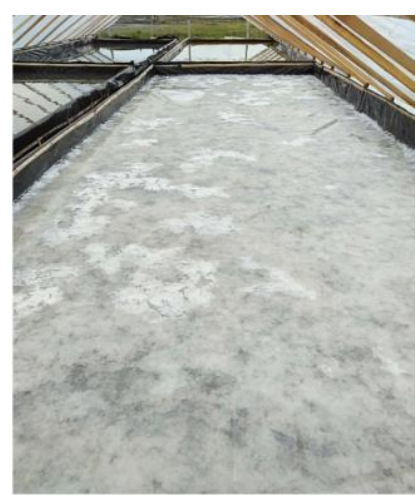

(a)

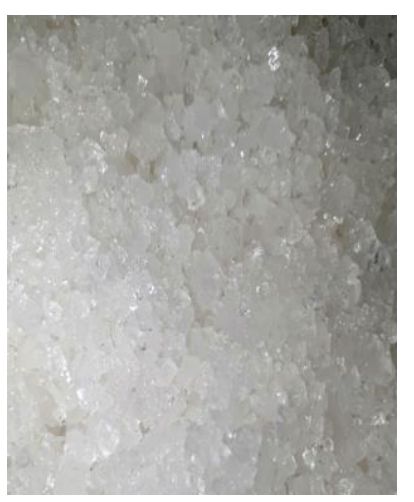

(b)
Gambar 3. Proses kristalisasi garam hari ke-10 (a) dan produk garam geomembran yang dihasilkan (b)
Pada penelitian ini, meja kristalisasi garam berjumlah empat meja dengan ukuran/meja P 9 × L 3,8 x T 0,20 meter diisi dengan air garam tua hingga mencapai ketinggian sekitar $8 \mathrm{~cm}$ dapat menghasilkan garam sebanyak $500 \mathrm{~kg} / \mathrm{meja}$ (pada kondisi musin kemarau) sehingga total produksi garam geomembran mencapai $2.000 \mathrm{~kg} /$ panen. Berdasarkan data dari Gambar 3 juga dapat dilihat bahwa produk garam geomembran berbentuk kristal berwarna putih mengkilat dan terlihat lebih kasar bila dibandingkan dengan bentuk garam tradisional.

\subsection{Mutu garam geomembran}

Mutu suatu produk sangat berpengaruh terhadap diterimanya produk tersebut oleh konsumen dimana semakin tinggi mutu produk semakin mempunyai nilai tambah dan semakin besar peluang untuk diterima di pasaran. Badan Standardisasi Nasional telah mengatur produk garam konsumsi yang dituangkan dalam bentuk SNI 3556:2010 (BSN, 2010).Pada peneltian ini, produk garam yang dihasilkan dari meja kristalisasi garam geomembran, sampelnya diambil dan dilakukan pengujian mutunya sesuai dengan SNI. Hasil pengujiannya dapat dilihat pada Tabel 3 .

Tabel 3.

Hasil uji produk garam geomembran dan perbandingannya dengan mutu SNI 3556:2010

\begin{tabular}{lllll}
\hline No. & Parameter Uji & Satuan & Hasil Uji & $\begin{array}{l}\text { Syarat } \\
\text { SNI }\end{array}$ \\
\hline 1. & Kadar air & $\%$ & 5,09 & Maks. 7 \\
2. & $\begin{array}{l}\text { Kadar natrium } \\
\text { klorida } \\
\text { (NaCl), adbk }\end{array}$ & & 96,4 & Min. 94 \\
& $\begin{array}{lll}\text { Cemaran } \\
3 .\end{array}$ & & & \\
& logam & & & \\
3.1 & Kadmium & $\mathrm{mg} / \mathrm{kg}$ & $<0,0002^{*}$ & Mak. 0,5 \\
& (Cd) & & & \\
3.2 & Timbal $(\mathrm{Pb})$ & $\mathrm{mg} / \mathrm{kg}$ & $<0,0001^{*}$ & Mak. 10,0 \\
3.3 & Raksa $(\mathrm{Hg})$ & $\mathrm{mg} / \mathrm{kg}$ & $<0,0005^{*}$ & Mak. 0,1 \\
3.4 & Arsen $(\mathrm{As})$ & $\mathrm{mg} / \mathrm{kg}$ & $<0,0002^{*}$ & Mak. 0,1 \\
\hline
\end{tabular}

* Batas deteksi alat

Berdasarkan data dari Tabel 3 diketahui bahwa produk garam yang berasal dari lahan geomembran memiliki kandungan air sebesar 5,09\%. Kandungan air di dalam garam tersebut sudah rendah dan telah memenuhi ambang batas SNI. Hasil uji kadar $\mathrm{NaCl}$ menunjukkan hasil sebesar 96,4\% dimana hasil uji ini lebih tinggi dari mutu standar SNI yang mensyaratkan kadar $\mathrm{NaCl}$ di dalam garam konsumsi Min. 94\%.

Salah satu kelebihan dari penggunaan geomembran pada pembuatan garam adalah proses pengkristalan garam dapat dilakukan tanpa harus bersentuhan langsung dengan tanah secara langsung menyebabkan garam yang dihasilkan tidak bercampur dengan polutan pada tanah sehingga garam yang dihasilkan lebih putih, bersih dan kandungan $\mathrm{NaCl}$ yang lebih tinggi (Arif Abdullah and Susandini, 2018). Hasil pengujian cemaran logam (kadmium, timbal, raksa dan arsen) pada produk garam yang dihasilkan menunjukkan hasil yang lebih rendah dari ambang batas yang dipersyaratkan dalam SNI. Umumnya cemaran logam di dalam garam dipengaruhi 
oleh sumber air baku yang digunakan untuk kristalisasi garam. Menurut Kementerian Kelautan dan Perikanan, lokasi lahan tambak yang akan digunakan untuk pembuatan garam harus terhindar dari perairan yang tercemar, kondisi bersih, tidak terdapat sampah, jernih dan tidak terlalu banyak supresi zat padat (Samsiyah et al., 2019). Adanya kandungan logam terutama logam berat dapat membahayakan kesehatan manusia dan alam sekitarnya.

\subsection{Perbandingan garam geomembran dengan garam tradisional}

\subsubsection{Perbandingan kapasitas produksi}

Kapasitas produksi dapat diartikan sebagai jumlah maksimum output yang dapat diproduksi atau dihasilkan dalam satuan waktu tertentu di mana semakin besar kapasitas produksi suatu produk akan semakin menguntungkan. Pada proses produksi garam, kapasitas produksi dihitung dari jumlah garam yang dihasilkan dalam jangka waku tertentu. Pada perhitungan kapasitas produksi ini, dihitung berdasarkan jumlah tenaga kerja yang dibutuhkan (1 orang), periode panen (10 hari). Hasil perbandingan kapasitas produksi antara garam dari lahan geomembran dengan garam yang dihasilkan secara tradisional/panen dapat dilihat pada Gambar 4.

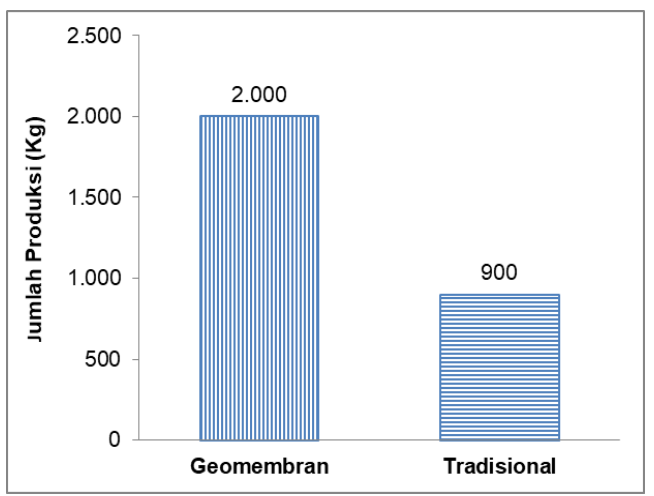

Gambar 4. Perbandingan produksi garam antara lahan geomembran dan cara tradisional menggunakan satu orang tenaga kerja.

Berdasarkan data dari Gambar 4 diketahui bahwa untuk masa panen selama 10 hari dengan lahan geomembran berjumlah empat unit dengan ukuran $\mathrm{P} 9 \mathrm{x}$ L 3,8 x T 0,20 meter/meja dapat dikelola oleh satu orang tenaga kerja yang menghasilkan $2.000 \mathrm{~kg}$ garam/panen. Sementara, garam tradisional yang diolah menggunakan kayu bakar dengan ukuran meja kristalisasi P 2,4 x L 1,2 x $\mathrm{T}$ 0,20 meter hanya dapat menghasilkan garam sebanyak $90 \mathrm{~kg} /$ hari, maka dalam 10 hari rata-rata dapat menghasilkan garam sebanyak $900 \mathrm{~kg}$ saja. Sementara, produksi garam dari lahan geomembran dalam 10 hari kerja dengan hanya satu orang tenaga kerja dapat memproduksi garam sebanyak $2.000 \mathrm{~kg} / \mathrm{empat}$ meja geomembran atau terjadi peningkatan produksi sebesar $122,22 \%$. Selain itu, proses produksi garam tradisional sangat mengandalkan tenaga kerja agar dapat terus berproduksi dan jika tenaga kerja berhalangan maka produksi akan terhenti. Sementara, lahan geomembran mengandalkan sinar matahari sedangkan tenaga kerja hanya bertugas untuk mengawasi saja dan memanen garam jika sudah waktunya dipanen.

Dalam penelitiannya, Suhendra, (2016) menyatakan bahwa dengan menggunakan lahan garam geomembran dapat meningkatkan jumlah produksi garam secara signifikan. Dalam penelitiannya di lahan milik PT. Garam Madura menunjukkan, dengan penggunaan geomembran dapat meningkatkan jumlah produksi garam mencapai $460 \%$ dibandingkan dengan lahan garam tanpa geomembran.

\subsubsection{Perbandingan kadar $\mathrm{NaCl}$}

Salah satu parameter yang paling menentukan pada mutu dan nilai jual garam adalah pada tingkat kemurnian garam yang dinyatakan dalam kadar $\mathrm{NaCl}$. Semakin tinggi kadar $\mathrm{NaCl}$ semakin murni garam tersebut dan sebaliknya. Pada penelitian ini, sampel garam dari lahan geomembran dan garam tradisional diambil dan dilakukan pengujian kadar $\mathrm{NaCl}$. Hasil pengujian kadar $\mathrm{NaCl}$ dari dua jenis garam tersebut dan nilai standar SNI dapat dilihat pada Gambar 5.

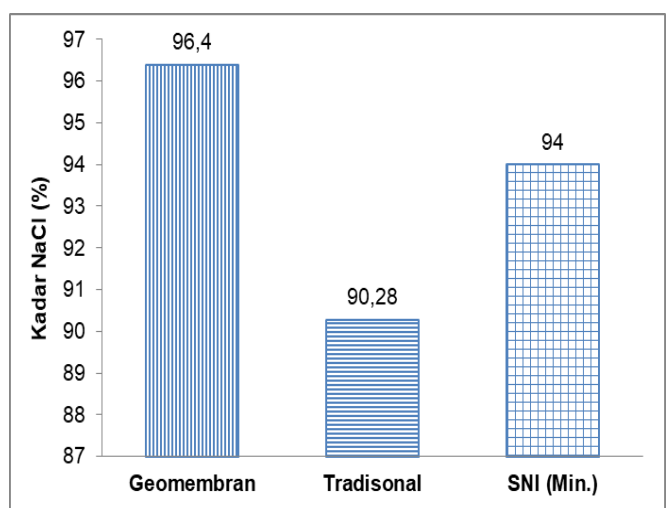

Gambar 5. Perbandingan kadar $\mathrm{NaCl}$ garam geomembran, garam tradisional dan nilai SNI.

Hasil uji kadar $\mathrm{NaCl}$ dalam kedua produk garam menunjukkan hasil kadar $\mathrm{NaCl}$ dalam garam tradisional sebesar 90,28\% sementara garam geomembran mengandung $\mathrm{NaCl}$ sebesar $96,4 \%$ lebih tinggi $6,12 \%$ dari kadar $\mathrm{NaCl}$ garam tradisional. Salah satu keunggulan dari garam geomembran adalah tingkat kemurnian garam lebih tinggi dari garam tradisional disebabkan karena geomembran terbuat dari bahan HDPE merupakan bahan dengan daya tahan tinggi yang memungkinkan untuk menahan tanah tambak dan kotoran tidak merembes ke dalam air laut selama proses kristalisasi garam terbentuk sehingga garam yang dihasilkan mempunyai tingkat kemurnian yang lebih tinggi dan bebas dari bahan pengotor (Pranowo and Muhajir, 2015).

\subsubsection{Perbandingan warna garam}

Umumnya warna garam dipengaruhi oleh tingkat kemurnian dan banyaknya jumlah pengotor yang ada di dalam garam tersebut di mana semakin putih warna garam semakin murni dan semakin kecil jumlah pengotor yang terkandung di dalam garam tersebut. Adapun perbedaan warna garam antara produk garam 
geomembran dengan produk garam tradisional dapat dilihat pada Gambar 6.

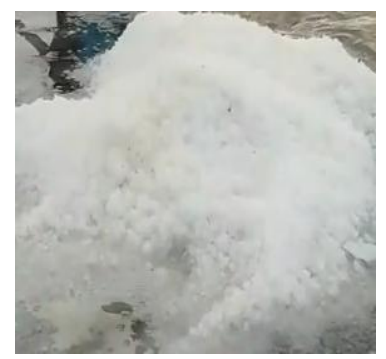

(a) Garam geomembran

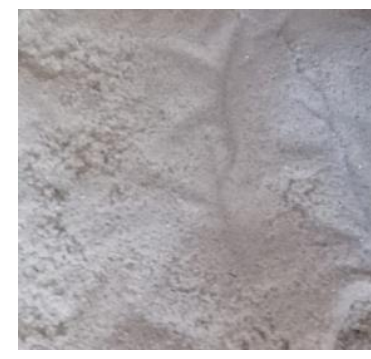

(b) Garam tradisional Gambar 6. Perbandingan warna garam.

Berdasarkan Gambar 6 dapat dilihat bahwa garam geomembran memiliki warna yang lebih putih mengkilat, sementara garam tradisional memiliki warna putih buram. Hal ini dipengaruhi oleh beberapa faktor diantaranya tingkat kemurnian garam. Garam geomembran mempunyai tingkat kemurnian lebih tinggi dengan tingkat pengotor yang lebih sedikit sehingga berwarna putih bersih, sedangkan garam tradisional memiliki banyak pengotor sehingga berwarna putih buram. Hal lainnya yag membuat warna garam tradisional putih buram adalah pengaruh pemasakan di mana sebagian besar garam yang dimasak dengan kayu bakar akan terpapar suhu yang tinggi sehingga gosong dan warnanya berubah menjadi putih buram.

\section{Kesimpulan}

Kesimpulan yang diperoleh dari penelitian proses pembuatan garam di lahan geomembran berlokasi di Desa Tanoh Anoe Kec. Jangka, Kab. Bireuen Prov. Aceh yaitu Hasil survey lokasi menunjukkan lahan yang dijadikan tempat penelitian sangat cocok untuk dijadikan lahan garam geomembran karena memiliki kondisi lingkungan yang ideal diantaranya memiliki curah hujan 1,447 $\mathrm{mm}$ dengan rata-rata curah hujan 92 hari/tahun, temperatur $32-38{ }^{\circ} \mathrm{C}$ dengan tingkat kelembaban udara 45-50\% dan kecepatan angin 4-5 m/detik. Untuk hasil pengujian air baku dari sumur bor yang digali di lahan tersebut menunjukkan kadar $\mathrm{NaCl}$ sebesar 3,78\% dan tidak terdekteksi adanya kandungan logam yang berbahaya, sedangkan proses kristalisasi garam di empat meja kristaliasi garam geomembran dengan ukuran masing-masing P 9 x L 3,8 x T 0,20 meter diisi dengan air garam tua hingga mencapai ketinggian sekitar $8 \mathrm{~cm}$ dapat menghasilkan garam sebanyak $500 \mathrm{~kg} / \mathrm{meja}$ (pada kondisi musim kemarau) sehingga total produksi garam geomembran mencapai $2.000 \mathrm{~kg} /$ panen.

Berdasarkan hasil pengujian $\mathrm{NaCl}$ dari produk garam geomembran menunjukkan hasil sebesar 96,4\%, dan tidak terdapat kandungan logam berbahaya. Hasil ini telah memenuhi persyaratan mutu SNI 3556:2010. Dibandingkan dengan garam tradisional yang dimasak menggunakan kayu bakar, lahan geomembran dapat menghasilkan garam lebih banyak dengan selisih sebesar $1.100 \mathrm{~kg} / 10$ hari atau terjadi peningkatan produksi sebesar 122,22\%. Hasil uji kadar $\mathrm{NaCl}$ menunjukkan kadar $\mathrm{NaCl}$ garam geomembran lebih tinggi 6,12\% dari garam tradisional. Sementara, hasil pengujian warna menunjukkan garam geomembran berwarna putih mengkilat, sementara garam tradisional memiliki warna putih buram.

\section{Ucapan terima kasih}

Pada kesempatan ini penulis mengucapkan terima kasih kepada Pusat Penelitian dan Pengembangan Industri Agro, Badan Penelitian dan Pengembangan Industri (BPPI), Kementerian Perindustrian RI yang telah memberikan dana penelitian dan Balai Riset dan Standardisasi Industri Banda Aceh yang telah memberikan fasilitas tempat pengujian produk dan UD. Milhy Jaya Bireuen yang telah memberikan lahan dan bimbingannya untuk kelancaran penelitian ini.

\section{Daftar pustaka}

Adi, T.R., Supangat, A., Sulistyo, B., S, B.M., Amarullah, H., Prihadi, T.H., Sudarto, Soentjahjo, E., Rustam, A., 2006. Buku panduan pengembangan usaha terpadu garam dan artemia.

Amien, D. Al, Adrienne, F., 2020. Tantangan dan potensi garam nasional.

Arif Abdullah, Z., Susandini, A., 2018. Media produksi (Geomembrane) dapat meningkatkan kualitas dan harga jual garam (Study kasus : ladang garam milik rakyat Di wilayah Madura). Eco-Entrepreneurship 3, 21-36.

Arwiyah, Zainuri, M. dan, Efendy, M., 2015. Studi kandungan $\mathrm{NaCl}$ di dalam air baku dan garam yang dihasilkan serta produktivitas lahan garam menggunakan meja garam yang berbeda. J. Kelaut. Indones. J. Mar. Sci. Technol. 8, 1-9.

BSN, 2010. SNI 3556:2010 Garam konsumsi beryodium. Badan Standardisasi Nasional.

Guntur, G., Jaziri, A.A., Prihanto, A.A., Arisandi, D.M., Kurniawan, A., 2018. Development of salt production technology using prism greenhouse method. IOP Conf. Ser. Earth Environ. Sci. 106. https://doi.org/10.1088/1755-1315/106/1/012082

Hoiriyah U., Y., 2019. Peningkatan kualitas produksi garam menggunakan teknologi geomembran 6, 3542.

Karya, C.B., 2015. Profil kabupaten Bireuen 1-30.

Lasabuda, R., 2013. Pembangunan wilayah pesisir dan lautan dalam perspektif negara kepulauan Republik Indonesia. J. Ilm. Platax 1, 92. https://doi.org/10.35800/jip.1.2.2013.1251

Mauliza, A., Suryadi, Murdani, 2016. Faktor-faktor yang mempengaruhi produksi garam rakyat di kecamatan Seunuddon kabupaten Aceh Utara. AGRIFO 1.

Pranowo, S.A., Muhajir, 2015. Dukungan klinik iptek mina bisnis (KIMBis) pada program pemberdayaan usaha garam rakyat (PUGAR) di kabupaten Pati. Bul. Ilm. "MARINA" Sos. Ekon. Kelaut. dan Perikan. 1, 19-28.

Rochwulaningsih, Y., 2018. Salt production business potential in Aceh as capital for the coastal communities welfare. J. Marit. Stud. Natl. Integr. 2, 23. https://doi.org/10.14710/jmsni.v2i1.2882

Samsiyah, N., Moelyaningrum, A.D., Ningrum, P.T., 
2019. Garam Indonesia berkualitas: Studi kandungan logam berat timbal $(\mathrm{Pb})$ pada garam. J. Ilm. Perikan. Dan Kelaut. 11, 43-48.

Santosa, I., 2014. Pembuatan garam menggunakan kolam kedap air berukuran sama. Spektrum Ind. 12, $1-112$.
Suhendra, A., 2016. Increasing the productivity of salt through HDPE geomembrane - Indonesian case history in salt evaporation pond. Ejge 21, 4273-4280.

Tansil, Y., Belina, Y., Widjaja, T., 2016. Produksi garam farmasi dari garam rakyat. J. Tek. ITS 5, 0-4. https://doi.org/10.12962/j23373539.v5i2.16427 